jixh

ACHNR

\section{Asian Community Health Nursing Research}

Asian Comm. Health Nurs. 2020, 2(2), 53-58

\title{
Relationship between Nurse Competence and the Performance Achievement of Public Health Nursing Program at Community Health Center
}

\author{
Andy Nuriyanto*, Laili Rahayuwati, Mamat Lukman \\ Faculty of Nursing, Universitas Padjadjaran \\ Email: nuriyantoandy@yahoo.co.id, lailira2002@yahoo.com, mamat.lukman@unpad.ac.id \\ Type of the Paper (Article) \\ Received: July 20, 2020; Accepted: August 25, 2020; Published: September 5, 2020 \\ https://doi.org/10.29253/achnr.2020.25338
}

\begin{abstract}
For Public Health Nursing program is an integration of the implementation public health and individual health program conducted at the community health centers to improve the independence and the health status of the community level. Public Health Nursing performance is a value of the public health nursing program implementation based on indicators as a benchmark for achieving of Minimum Achievement Standard goals. In order to achieve their performance, nurses have competencies and authorities based on their position in accordance with the applicable regulations and are carried out in according to their main duties and functions. his study aims to determine the relationship between nurse competence and the achievement of Public Health Nursing program at the community health centers. This study used cross-sectional approach form secondary data with quantitative methods with the samples of 57 nurses (44 vocational and 13 professional nurses). The data was obtained from the performance assessment of the Community Health Centers (PKP 2019) of the 5 Community Health Centers in Berau District during 2019. Data analysis was using Pearson Product Moment for bivariate and Path Analysis for multivariate analysis to determine the relationship between vocational nurse competence and professional nurse competence variables with the performance achievement of the public health nursing at the CHCs. The findings indicated that there were significant relationships between competence of vocational nurses (p-value 0.026), professional nurses (p-value 0.000), and simultaneously both (p-value 0.004) and the achievement of Public Health Nursing program at the Community Health Centers. The evaluation of the nurse's competence is the basis for realizing the achievements of the Public Health Nursing program at the Community Health Centers in base on their functional position level. A more thorough analysis is required to determine the effect of implementing these competencies to increase the public health nursing performance at the Community Health Centers.
\end{abstract}

Keywords: Nurse Competence, Public Health Nursing Performance, Community Health Center

\section{Introduction}

Nursing is a professional practice of nursing care for the target of individuals, families, and groups/communities including both healthy and ill conditions (Mensekneg-RI, 2014). To meet the 
service criteria, a nurse is expected to have the competence to act smartly and be based on responsibility as recognition of the ability to carry out roles, main tasks and functions in their field of work. According to the International Council of Nurses (ICN), nursing competencies include: 1) professional, legal and ethical aspects of nursing practice, 2) service providers and nursing management, and 3) nursing professional development (Schober \& Affara, 2009). Based on these three main competencies, nursing professionals must have 3 (three) basic skills consisting of intellectual, technical and interpersonal relationships.

According to the nursing education curriculum, nurses are required to be able to act as nursing service providers, case decision makers, communicators, and case managers at the individual, family and community levels (Murray, 2004). Through these roles, increased independence of work targets is expected to be able to prevent and solve problems and improve the quality of health independently (Nuriyanto \& Rahayuwati, 2019).

The regulation of the Ministry of Empowerment of State Apparatus and Bureaucratic Reform of the Republic of Indonesia or Permenpan RI (2014) states that each nurse has a scope of duties, responsibilities, and authority to carry out service activities in accordance with the level of functional position they occupy. In this regulation, nurses are divided into 2 types consisting of vocational nurses with a minimum educational background of Diploma 3 and professional nurses with a minimum educational background of Nurse Professional Education (Mensekneg-RI, 2014).

The phenomenon that currently occurs showed that when nurses carried out their main duties and functions without understanding the limits of their functional position, they tended to have a high workload and did not focus on their authority. The lack of understanding of nurses about their duties and functions in health services had an impact on the limited concentration of nurses' role in the realm of immunization and basic health services. Even though nurses were able to carry out duties in all lines of government health services, they tended to ignore their main duties and functions (Ma, Meng, Wei, \& Li, 2019). Thus, community nurses are assumed to carry out activities based on habits that lead them to be more skilled at enforcing disease diagnoses than nursing diagnoses (Handayaningsih, 2019). In fact, public health nurses have the duty and function to achieve the program performance indicators that have been set in the policies at the community health center level as a derivative form of the superior policies (Nuriyanto, 2020).

Based on this phenomenon, Ma et al. (2019) provides recommendations to determine performance indicators in detail and conduct socialization or training of nurse performance according to their main duties. This is in accordance with the Permenpan RI (2014) policy which requires that assessment of nurse performance be carried out routinely based on their authority based on their level of functional position. Assessment of nurse performance based on their authority is called a Workload Analysis (ABK) to meet the needs of nursing resources in health facilities (Kemenkes RI, 2020; Permenpan RI, 2014). This analysis is expected to be able to achieve an optimal increase in the performance of the public health nursing program at the community health centers.

Based on the background described above, this study aims to determine the relationship between the nurse competence and the performance achievement of public health nursing program at the Community Health Centers (CHCs).

\section{Method}

This study was conducted in a quantitative analysis manner with a specific cross- sectional approach at City Community Health Centers (CHCs) based on secondary data obtained from the CHCs Performance Assessment report during the period 2019. The study samples were 57 nurses consisting of 44 vocational nurses and 13 professional nurses who served in 5 (five) CHCs in the city area of Berau District.

Data collection instrument to assess nurse competence variable used here was the RENBUT application taken from www.renbut.kemkes.go.id website in accordance with the Regulation of Permenpan 25/2014 concerning Nursing Functional Levels. The performance achievement variable of the public health nursing program was calculated based on the comparison between the target program performance indicator and the performance achievement of the public health nursing program at CHCs. The data was obtained from the performance assessment of the CHCs (PKP 2019) of the 5 Community Health Centers in Berau District during 2019. 
Data analysis was carried out univariately to determine the mean score of nurse competence and performance achievement of the public health nursing program in each work area of the CHCs. Bivariate analysis was carried out using Pearson Product Moment for bivariate and Path Analysis for multivariate analysis to determine the relationship between vocational nurse competence and professional nurse competence variables with the performance achievement of the public health nursing at the CHCs. Accumulatively, the relationship between the two was analyzed using the Annova test with a significance level of 0.05 and a confidence level of $95 \%$. This study has received a clearance from the Berau District Health Office number 112/YANKES-PRIMER/VI/2020.

\section{Results}

\subsection{Nurse Competence Assessment}

Table 1. Assessment of Vocational Nurse Competence

\begin{tabular}{cccccc}
\hline CHCs & Count & Min & Max & Average & Std. Dev \\
\hline Tanjung Redeb & 9 & 65.00 & 77.00 & 72.22 & 4.52 \\
Gunung Tabur & 8 & 67.00 & 81.00 & 74.50 & 4.56 \\
Merancang & 9 & 68.00 & 80.00 & 75.44 & 3.50 \\
Sambaliung & 10 & 71.00 & 81.00 & 75.70 & 3.30 \\
Kampung Bugis & 8 & 69.00 & 79.00 & 75.62 & 3.29 \\
\hline
\end{tabular}

Table 1 provides an explanation that the mean competence of vocational nurses in all study sites was 74.70. The highest mean competence was found among 10 vocational nurses on duty at Sambaliung CHC located in urban area by 75.70 (Std. Dev 3.30).

Table 2. Assessment of Professional Nurse Competence

\begin{tabular}{cccccc}
\hline CHCs & Count & Min & Max & Average & Std. Dev \\
\hline Tanjung Redeb & 2 & 74.00 & 74.00 & 74.00 & 0.00 \\
Gunung Tabur & 2 & 74.00 & 76.00 & 75.00 & 1.41 \\
Merancang & 3 & 73.00 & 82.00 & 77.66 & 4.50 \\
Sambaliung & 3 & 75.00 & 84.00 & 78.66 & 4.72 \\
Kampung Bugis & 3 & 76.00 & 81.00 & 78.33 & 2.51 \\
\hline \multicolumn{5}{c}{ Average } & 76.73 \\
\hline
\end{tabular}

Table 2 provides an explanation that the mean competence of professional nurses in all study sites was 76.73. The highest mean competence was found among 3 nurses on duty at Sambaliung CHC by 78.66 (Std. Dev 4.72).

\subsection{Public Health Nursing Performance Achievement Assessment}

Table 3. Performance Achievement of Public Health Nursing at CHCs

\begin{tabular}{ccc}
\hline CHCs & Value & Average \\
\hline Tanjung Redeb & 75.67 & 79.37 \\
Gunung Tabur & 77.32 & \\
Merancang & 81.12 & \\
Sambaliung & 82.23 & \\
Kampung Bugis & 82.31 & \\
\hline
\end{tabular}

Table 3 explains that the performance achievement of the CHCs obtained a mean score of 79.37 with the highest score found in Kampung Bugis CHC (82.31). Kampung Bugis CHC is the first level health facility in the city area with the closest distance to the Berau District Health Office. This is a value added so that Kampung Bugis Health CHC can be faster and work together in coordination with the Health Office.

\subsection{Relationship between Nurse Competence and Performance Achievement of Public Health Nursing}

Table 4 explains that there was a significant relationship between both the competence of vocational nurses $(r=0.922$, $p$-value $=0.026)$ and professional nurse competence $(r=0.997, p$-value $=0.000)$ with the performance achievement of public health nursing program. 
Table 4. Analysis of the relationship between nurse competence and performance achievement of the public health nursing program

\begin{tabular}{cccccc}
\hline \multicolumn{6}{c}{ Performance Achievement of Public Health Nursing } \\
\hline & $\begin{array}{c}\text { Pearson } \\
\text { Correlation }\end{array}$ & $\begin{array}{c}\text { Sig. (2- } \\
\text { tailed) }\end{array}$ & $\begin{array}{c}\text { Standardized } \\
\text { Coefficients }\end{array}$ & $\begin{array}{c}\text { R } \\
\text { Square }\end{array}$ & Sig. \\
\hline $\begin{array}{c}\text { Vocational Nurse } \\
\text { Competences } \\
\text { Professional Nurse }\end{array}$ & 0.922 & 0.026 & 0.073 & 0.996 & 0.004 \\
\hline
\end{tabular}

In addition, the predictors of competence of vocational nurses and professional nurses simultaneously had a close relationship with a contribution of $99.6 \%$ (R Square $=0.996$, $p$-value $=0.004$ ) in achieving the performance of public health nursing program at the CHCs.

\section{Discussion}

\subsection{Nurse Competence Assessment}

Community nursing services refer to the nursing team structure, nursing processes, and community nursing outcomes (Campbell, Harmon, Joyce, \& Little, 2020). The structure of the nurses on duty at the Sambaliung CHC (table 1 and table 2) showed the highest number in comparison to other CHCs (10 vocational nurses and 3 professional nurses). This is in accordance with the concept of Campbell et al. (2020) which states that the structure of a community nursing team makes a measure of their educational qualifications and competence experience. Thus, cooperation between nursing implementers can run optimally to achieve the expected competencies.

In all work areas of $\mathrm{CHCs}$, the competence assessment of vocational nurses according to their functional position includes skilled nurses, proficient nurses, and supervisory nurses. Meanwhile, the competence assessment of professional nurses includes first expert nurses and young expert nurses. All CHCs used the RENBUT instrument based on Permenpan 25/2014 taken from the www.renbut.kemkes.go.id website regularly and reported in the form of CHC Performance Assessment (PKP). Thus, the nurse competence assessment conducted at all CHCs was in accordance with the level of functional position based on educational qualification and competence experience.

\subsection{Public Health Nursing Performance Achievement Assessment}

Base on the result from Table 3, Kampung Bugis CHC is the highest score for the Achievement Performance of Public Health Nursing at CHCs. Community nursing application discusses the contribution of time and team competence that allows efficiency and adherence to the schedule of the activity implementation process. The methods required in the community nursing process are collaboration/cooperation, regularity, and the work cycle. So, the expected outcome is a strategy to determine where, when, and how the competence of nurses is used to achieve goals based on performance indicators (Campbell et al., 2020).

The cycle of health program activities at CHC is explained in the Ministry of Health of the Republic of Indonesia (Kemenkes RI, 2016b) that every health program must implement a Plan-Do-Check-Action (PDCA) cycle. The cycle starts from planning, which is led by the person in charge of the health program to determine an activity plan (Plan) for a certain period of time. Program activities are then carried out according to the agreed schedule (Do) and monitoring is carried out based on existing performance indicators (Check). The output of the monitoring is the achievement of program performance that must be followed up (Action) to form program performance achievement (Kemenkes RI, 2016a).

\subsection{Relationship between Nurse Competence and Performance Achievement of Public Health Nursing}

According to the International Council of Nurses (ICN), nursing professional competence includes: 1) professional, legal and ethical aspects of nursing practice, 2) nursing service and management providers, and 3) nursing professional development (Schober \& Affara, 2009). In practice, besides acting as caregivers, case finder, communicator, community leader, and case manager the important role of nurses at the community level is as change agents by using the Community as Partner model (Murray, 
2004). The goal is that health service users do not depend on nurses or other healthcare workers to solve the health problems they face (Nuriyanto, 2020).

Nursing is a professional practice of nursing care for the target of individuals, families, and groups/communities including both healthy and ill conditions (Mensekneg-RI, 2014). Each level of nursing position has duties and functions according to its regulatory limits. The application of the plan for the needs of healthcare workers (RENBUT) at the CHC based on the Mensekneg-RI (2014) states that the competence of nurses is differentiated by level of position according to educational background and years of service.

Table 5. Competence domains of nurses according to the level of functional position, adopted from the nurse duties and functions based on Permenpan RI 25/2014.

\begin{tabular}{|c|c|c|c|c|c|c|c|c|}
\hline \multirow[b]{2}{*}{$\begin{array}{c}\text { Level of Nurses } \\
\text { Functional Position }\end{array}$} & \multicolumn{3}{|c|}{ Assessment } & \multicolumn{3}{|c|}{ Intervention } & \multicolumn{2}{|c|}{$\begin{array}{c}\text { Evaluati } \\
\text { on }\end{array}$} \\
\hline & ڤే & 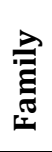 & $\stackrel{\Xi}{\Xi}$ & ڤే & 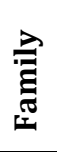 & $\stackrel{\Xi}{\Xi}$ & 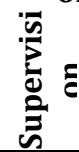 & 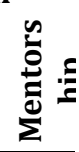 \\
\hline Skilled Nurse & $\mathrm{V}$ & - & - & $\mathrm{V}$ & $\mathrm{V}$ & $\mathrm{V}$ & V & - \\
\hline Proficient Nurse & $\mathrm{V}$ & V & - & V & $\mathrm{V}$ & V & V & - \\
\hline Supervisory Nurse & $\mathrm{X}$ & $\mathrm{V}$ & V & $\mathrm{V}$ & $\mathrm{V}$ & $\mathrm{X}$ & $\mathrm{X}$ & - \\
\hline First Expert Nurse & $\mathrm{X}$ & $\mathrm{X}$ & $\mathrm{V}$ & $\mathrm{X}$ & $\mathrm{X}$ & V & - & V \\
\hline Young Expert Nurse & $\mathrm{X}$ & $\mathrm{X}$ & $\mathrm{X}$ & $\mathrm{X}$ & $\mathrm{X}$ & $\mathrm{X}$ & - & $\mathrm{X}$ \\
\hline Middle Expert Nurse & $\mathrm{X}$ & $\mathrm{X}$ & $\mathrm{X}$ & $\mathrm{X}$ & $\mathrm{X}$ & $\mathrm{X}$ & - & $\mathrm{X}$ \\
\hline Main Expert Nurse & $\mathrm{X}$ & $\mathrm{X}$ & $\mathrm{X}$ & $\mathrm{X}$ & $\mathrm{X}$ & $\mathrm{X}$ & - & $\mathrm{X}$ \\
\hline
\end{tabular}

Information: $\mathrm{V}=$ Basic Level $\mathrm{X}=$ Advance Level

Current perceptions of nurses showe that they had competence in the form of the same roles and functions at all levels of functional positions (Handayaningsih, 2019). The lack of understanding of nurses about their duties and functions in health services had an impact on the limited concentration of nurses' role in the realm of immunization and basic health services. Even though nurses were able to carry out duties in all lines of government health services, they tended to ignore their main duties and functions (Ma et al., 2019). Based on this, it can be assumed that community nurses carry out activities based on habits that are often carried out in daily life. This also happens in Indonesia, which leads the nurses to be more skilled at enforcing disease diagnoses than nursing diagnoses (Handayaningsih, 2019).

In this study, it was shown that the competence of professional nurses ( $r=0.997, p$ - value $=0.000)$ had a more significant level of significance than the performance of vocational nurses $(r=0.922$, $p$ value $=0.026$ ) on the performance achievement of the public health nursing program (Table 4). This is in accordance with the duties and functions of nurses based on the level of their functional position (see table 5). To be able to carry out integrated community nursing in the public health nursing program, nurses are required to be at least at the supervisory level (vocational nurse with years of service of about 12 years) or at least the first expert level (professional nurse with years of service of 0 years).

\section{Conclusion}

The findings of this study indicated that there were significant relationships between competences of vocational and professional nurses with the performance achievement of the public health nursing program, both individually and simultaneously. The competence of professional nurses had a greater contribution than vocational nurses in achieving program performance. Competence as described related to the main duties and functions of nurses based on educational background and experience or years of service.

Community health nurses have the authority according to the level of functional position they occupy. The integrated nursing process in the health care program in accordance with applicable regulations requires nurses to have a minimum position at the supervisory nurse level or the first expert nurse level. This is mandatory for CHC to have at least the resource of the supervisory nurses or first expert in their work area so that the public health nursing performance can be implemented in accordance with the competencies held according to the level of nursing professional position. 
Even though the results of this research could not be generalized, the findings are likely to be applicable within similar condition settings for any public health facilities. Further research is needed to examine the effectiveness of nursing competence towards the public health nursing performance achievements in the work area of community health center.

\section{Acknowledgements}

The current article is extracted from Performance Assessment of Public Health Center and approved by 5 Community Health Centre in Berau District - East of Borneo. The authors would like to thank and appreciate all nurses and Leaders of Community Health Centre and head of health department in Berau District - East of Borneo.

\section{References}

Campbell, L. A., Harmon, M. J., Joyce, B. L., \& Little, S. H. (2020). Quad Council Coalition community/public health nursing competencies: Building consensus through collaboration. Public Health Nursing, 37(1), 96-112.

Handayaningsih, I. (2019). Dokumentasi Keperawatan" DAR" Panduan, Konsep, dan Aplikasi.

Kemenkes RI. (2016a). Permenkes Nomor 43 tahun 2016 tentang Manajemen Puskesmas. Jakarta: Kemenkes RI

Kemenkes RI. (2016b). Permenkes Nomor 44 tahun 2016 tentang Pedoman Manajemen Puskesmas. Jakarta: Kemenkes RI

Kemenkes RI. (2020). Website Rencana Kebutuhan Tenaga Kesehatan di Puskesmas. Retrieved from http://renbut.kemkes.go.id/

Ma, W., Meng, X., Wei, Y., \& Li, J. (2019). Roles and activities of community nurses in China: A descriptive study. Journal of Nursing Management.

Mensekneg-RI. (2014). Undang-undang Nomor 38 tahun 2014 tentang Keperawatan. Jakarta

Murray, I. (2004). Family health nursing: the education programme for the WHO Europe Scottish Pilot. British journal of community nursing, 9(6), 245-250.

Nuriyanto, A. (2020). Perkesmas: Praktik Keperawatan Profesional di Puskesmas. Surakarta: CV Kekata Group.

Nuriyanto, A., \& Rahayuwati, L. (2019). Family Nursing as an Improvement Strategy of Family Health Index in Indonesia: A Literature Review. Asian Community Health Nursing Research, 1(3), 7-16. doi:https://doi.org/10.29253/achnr.1.3.2019.21

Permenpan RI. (2014). Peraturan Menteri Pemberdayagunaan Aparatur Negara dan Reformasi Birokrasi Republik Indonesia Nomor 25 tahun 2014 tentang Jabatan Fungsional Perawat dan Angka Kreditnya. Jakarta: Menteri Pemberdayagunaan Aparatur Negara dan Reformasi Birokrasi Republik Indonesia

Schober, M., \& Affara, F. (2009). International Council of Nurses: advanced nursing practice: John Wiley \& Sons. 